\title{
INTEGRASI SOSIAL UMAT BUDDHA TANGERANG PESISIR
}

\author{
Oleh: Nyoto ${ }^{1 *}$, Waluyo ${ }^{2}$, Lalita Vistari Satyananda Wiryana Dharma ${ }^{3}$, Tuberto ${ }^{4}$ \\ 1Sekolah Tinggi Agama Buddha Negeri Sriwijaya \\ ${ }^{2}$ Sekolah Tinggi Agama Buddha Negeri Sriwijaya \\ ${ }^{3}$ Sekolah Tinggi Agama Buddha Negeri Sriwijaya \\ ${ }^{4}$ Sekolah Tinggi Agama Buddha Negeri Sriwijaya \\ *Korespondensi: mail.nyoto@gmail.com
}

(Received: tgl-bln-thn; Reviewed: tgl-bln-thn; Revised: tgl-bln-thn; Accepted: tgl-bln-thn; Published: tgl-bln-thn)

\begin{abstract}
This research is based on the main problem, namely the absence of a comprehensive picture of the Buddhists social integration of the Tangerang Coastal Zone who have unique characteristics while having potential in conflict prevention efforts. This study aims to describe the Buddhists social integration of Tangerang Coastal. This study uses a quantitative approach with descriptive analysis. Data was collected through non-test techniques, using questionnaires developed by the researcher. A sample of 294 were selected from a population of around 1,000 respondents. The questionnaire instrument has fulfilled the content validity with expert judgment and empirical validity using the product moment formula. The questionnaire reliability was tested by Cronbach's alpha formula. Data were analyzed using descriptive statistics. The results showed that: (a) the level of Buddhists social integration of Tangerang Coastal was $71 \%$ (good), with a high category of $20 \%$, medium $69 \%$, and low $11 \%$; (b) the proportion of Buddhists social integration of Tangerang Coastal based on variable dimensions, namely 1.00: 1.14: 1.19: 1.11; with the details of each percentage as follows: (1) integration process by $63 \%$, (2) integration forms by $72 \%$, (3) integration factors by $75 \%$, and (d) social solidarity by $70 \%$; (4) the process of integration of Buddhist of the Tangerang Coastal consisting of assimilation and acculturation indicators has a rate of $63 \%$ (sufficient), with a high category of $17 \%$, moderate $78 \%$, and a high of $5 \%$; (d) the form of integration of Buddhist of the Tangerang Coastal consisting of normative, functional, and coercive indicators having a level of $72 \%$ (good), with a high category of $20 \%$, moderate $67 \%$, and a high of $13 \%$; (5) the integration factor of Buddhist of Tangerang Coastal which consists of internal and external indicators has a level of $75 \%$ (good), with a high category of $17 \%$, medium $72 \%$, and high $11 \%$; (6) the social solidarity of Buddhist of Tangerang Coastal consisting of mechanical and organic indicators having a rate of $70 \%$ (good), with a high category of $19 \%$, medium $70 \%$, and low $11 \%$.
\end{abstract}

Keywords: Tangerang Coastal, Buddhist, social integration. 


\begin{abstract}
ABSTRAK
Penelitian ini didasarkan pada permasalahan utama yaitu belum adanya gambaran secara komprehensif mengenai integrasi sosial umat Buddha wilayah Tangerang Pesisir yang memiliki karakteristik unik sekaligus memiliki potensi dalam upaya pencegahan konflik. Penelitian ini bertujuan untuk mendeskripsikan integrasi sosial umat Buddha Tangerang Pesisir. Penelitian ini menggunakan pendekatan kuantitatif dengan analisis deskriptif. Data dikumpulkan melalui teknik nontes, menggunakan instrumen angket yang dikembangkan sendiri oleh peneliti. Sampel sejumlah 294 dipilih dari populasi sekitar 1.000 responden. Instrumen angket telah memenuhi validitas isi dengan expert judgment dan validitas empiris menggunakan rumus product moment. Reliabilitas angket diuji dengan rumus alpha Cronbach. Data dianalisis menggunakan statistik deskriptif. Hasil penelitian menunjukkan bahwa: (a) tingkat integrasi sosial umat Buddha Tangerang Pesisir sebesar 71\% (baik), dengan kategori tinggi sebesar 20\%, sedang 69\%, dan rendah 11\%; (b) proporsi integrasi sosial umat Buddha Tangerang Pesisir berdasarkan dimensi variabel, yaitu $1,00: 1,14: 1,19: 1,11$; dengan rincian persentase masing-masing sebagai berikut: (a) proses integrasi sebesar $63 \%$, (b) bentuk integrasi sebesar 72\%, (c) faktor integrasi sebesar 75\%, dan (d) solidaritas sosial sebesar 70\%; (c) proses integrasi umat Buddha Tangerang Pesisir yang terdiri dari indikator asimilasi dan akulturasi memiliki tingkat sebesar 63\% (cukup), dengan kategori tinggi sebesar $17 \%$, sedang 78\%, dan tinggi 5\%; (d) bentuk integrasi umat Buddha Tangerang Pesisir yang terdiri dari indikator normatif, fungsional, dan koersif memiliki tingkat sebesar $72 \%$ (baik), dengan kategori tinggi sebesar 20\%, sedang 67\%, dan tinggi 13\%; (e) faktor integrasi umat Buddha Tangerang Pesisir yang terdiri dari indikator internal dan eksternal memiliki tingkat sebesar $75 \%$ (baik), dengan kategori tinggi sebesar $17 \%$, sedang $72 \%$, dan tinggi 11\%; (f) solidaritas sosial umat Buddha Tangerang Pesisir yang terdiri dari indikator mekanis dan organis memiliki tingkat sebesar $70 \%$ (baik), dengan kategori tinggi sebesar $19 \%$, sedang $70 \%$, dan rendah $11 \%$.
\end{abstract}

Kata kunci: Tangerang Pesisir, umat Buddha, Integrasi sosial.

\title{
PENDAHULUAN
}

Kota Tangerang merupakan salah satu wilayah dari Provinsi Banten yang memiliki keragaman budaya dan agama. Banten merupakan provinsi yang berdiri berdasarkan Undang-Undang Nomor 23 Tahun 2000 secara administratif, terbagi atas empat kabupaten dan empat kota yaitu Kabupaten Serang, Kabupaten Pandeglang, Kabupaten Lebak, Kabupaten Tangerang, Kota Serang, Kota Tangerang Selatan, Kota Tangerang, dan Kota Cilegon, dengan luas $9.160 \mathrm{~km}^{2}$. Sesuai dengan hasil sensus tahun 2015 jumlah penduduk kurang lebih 11,83 juta jiwa.

Keragaman budaya dan agama yang ada di Banten dipengaruhi oleh faktor urbanisasi. Banten merupakan daerah industri yang mempekerjakan karyawan dari berbagai daerah di Indonesia. Selain Provinsi DKI Jakarta, Banten menjadi tujuan para pencari kerja, hal ini terjadi karena banyaknya perusahan yang beroperasi di Banten. Dengan banyaknya pendatang dari luar daerah maka akan muncul budaya baru yang memengaruhi masyarakat Banten. Banyaknya pendatang ke Provinsi Banten, khususnya Kabupaten Tangerang memunculkan budaya baru karena benturan berbagai macam budaya yang membentuknya. 
Mayoritas penduduk Banten beragama Islam, tetapi terdapat juga masyarakat yang beragama Kristen, Katolik, Buddha, Hindu, dan Konghucu. Dengan banyaknya budaya dan agama di Banten, maka diperlukan suatu cara atau strategi agar muncul rasa toleransi dan saling menghormati dalam kehidupan bermasyarakat. Kota Tangerang merupakan salah satu bagian dari Provinsi Banten yang sebagian penduduknya beragama Buddha. Pemeluk agama Buddha di Kota Tangerang mayoritas suku Tionghoa. Suku Tionghoa yang berada di Tangerang berasal dari Tiongkok yang mengikuti Laksamana Cengho yang berkunjung ke Nusantara. Keyakinan yang dibawa saat itu adalah Taoisme, Konfusianisme, dan Islam. Setelah tinggal dan terjadi pernikahan dengan penduduk setempat maka mulai terjadi perpindahan budaya dan kebiasaan termasuk menganut agama Buddha.

Warga Tionghoa di Tangerang banyak yang tinggal di pinggir Sungai Cisadane dan di pesisir laut, hal ini terjadi karena pada zaman dahulu nenek moyang orang Tionghoa menggunakan laut dan sungai sebagai jalur trasportasi. Bukti kuat fakta ini yaitu banyaknya tempat ibadah yang ada di tepi Sungai Cisadane dan pesisir laut Tangerang, misalnya keberanaan beberapa vihāra di tepi Sungai Cisadane ada Vihāra Padumutara (Boen Tek Bio), Vihāra Nimala (Boen San Bio), Vihāra Karunanyala (Boen Hai Bio). Vihāra di Tangerang Pesisir sebagai tempat ibadah orang Tionghoa di beberapa daerah, yaitu Tanjung Pasir, Tanjung Kait, Mauk, Kampung Melayu, Tanjung Burung, dan Teluk Naga.

Suku Tionghoa yang ada di pesisir Tangerang biasa dikenal dengan istilah Cina Benteng. Belum diketahui secara pasti mengapa suku Tionghoa di Tangerang dipanggil Cina Benteng. Suku Tionghoa yang ada di pesisir Tangerang sebagian beragama Buddha dapat diketahui dari banyaknya vihāra dan sekolah yang beryayasan Buddhis. Dengan banyaknya permasalahan sosial dan keagamaan yang terjadi, umat Buddha di pesisir Tangerang masih bertahan dan tetap beragama Buddha. Bertahannya umat Buddha di pesisir Tangerang karena dipengaruhi oleh integrasi sosial. Proses integrasi ini adalah semakin tipisnya batas perbedaan antarindividu dalam suatu kelompok, atau bisa juga batas-batas antarkelompok. Selanjutnya, individu melakukan identifikasi diri dengan mendasarkan pada kepentingan bersama. Artinya, orang seseorang menyesuaikan kemauannya dengan kemauan kelompok, demikian pula antara kelompok yang satu dengan kelompok lainnya.

Wilayah Tangerang bagian Utara secara geografis masuk dalam Provinsi Banten, yang dikenal dengan "Tangerang Pesisir" yang terhubung langsung dengan Teluk Jakarta. Namun demikian, kedekatan geografis ini tidak lantas menjadikan keduanya memiliki kesamaan, daya tarik, dan pertautan yang kuat. Bahkan, keduanya memiliki perbedaan yang mencolok. Banten cenderung kuat dalam oligarki kekuasaan politik, penguasaan sumber daya alam yang rendah, tertinggalnya pembangunan wilayah pesisir Tangerang menjadi indikator lemahnya sumber daya manusia.

Toleransi merupakan salah satu pedoman hidup umat Buddha di Tangerang pesisir. Jika sikap toleransi tidak dikembangkan maka bisa saja terjadi permasalahan sosial, misalnya kasus pembakaran vihāra yang terjadi di Tanjung Balai. Peristiwa tersebut terjadi karena minimnya rasa saling menghormati antarpemeluk agama (http://jateng.tribunnews.com/2016/07/31/kronologi-dan-penyebab-awal-kerusuhan-saradi-tanjungbalai). Kerusuhan bermula dari protes seorang warga berinisial M (41), warga Jalan Karya Kelurahan Tanjung Balai Kota I, Kecamatan Tanjung Balai Selatan Kota yang keberatan dengan volume pengeras suara Masjid Al Maksum yang terletak tak jauh dari 
kediamannya. M mendatangi masjid, meminta agar saat mengumandangkan azan maupun pengajian, volume suara dikecilkan.

Interaksi sosial di masyarakat yang terdiri dari banyak kelompok, suku, adat, ras, dan agama memungkinkan terjadinya permasalahan. Kehidupan sosial tidak pernah lepas dari konflik antarindividunya. Benturan berbagai kepentingan sebagai bagian dari masyarakat menimbulkan persaingan yang dapat menimbulkan konflik berkepanjangan. Secara sederhana konflik didefinisikan sebagai perselisihan atau persengketaan antara dua atau lebih kekuatan baik secara individu atau kelompok yang kedua belah pihak memiliki keinginan untuk saling menjatuhkan atau menyingkirkan atau mengalahkan atau menyisihkan. Heterogenitas suatu kelompok sering kali menimbulkan konflik antarsuku, agama, ras, dan golongan. Selain itu, jika diferensiasi sosial tidak ditangani secara bijak akan menimbulkan kerawanan konflik sosial. Di sisi lain, keanekaragaman sosiokultural justru menjadi kekayaan budaya yang akan menjunjung tinggi peradaban bangsa di mata kelompok sekitarnya, bahkan dunia internasional yang berdampak pada keuntungan ekonomis jika dikelola dengan baik. Konflik juga dapat disebabkan oleh adanya ketimpangan ekonomi yang terjadi di masyarakat karena adanya kecemburuan sosial.

Keragaman yang ada di Tangerang pesisir memiliki potensi konflik jika tidak diupayakan cara untuk menghindarinya. Berbagai usaha telah dilakukan untuk menghindari terjadinya konflik, di antaranya saling menghargai perbedaan dalam kehidupan bermasyarakat dan memprioritaskan kepentingan umum di atas kepentingan pribadi dan kelompok. Konflik memang melekat pada setiap kehidupan sosial, sehingga diperlukan adanya integrasi antarindividu yang hidup di masyarakat. Integrasi sosial timbul karena orientasi antarelemen sosial memiliki perasaan in group terhadap kelompoknya dan ada kelompok lain di luar kelompoknya (out group). Cara bertahan hidup, mata pencaharian, kehidupan sosial umat Buddha di Tangerang pesisir merupakan hal yang menarik untuk diketahui. Umat Buddha di Tangerang pesisir secara turun temurun sudah menyatu dengan masyarakat dan berbaur satu sama lain. Namun demikian, komunitas umat Buddha ini memiliki spesifikasi karakter yang kuat dalam membawa budaya, adat istiadat, kepribadian dalam membaur dengan masyarakatnya. Hal ini dapat menjadi sebab konflik di masyarakat jika tidak dipahami dengan baik. Bagaimana proses integrasi umat Buddha, apa pula bentuk dan faktor-faktor yang menyebabkannya, serta peran solidaritas sosial dalam mengikat komunitas umat Buddha sebagai bagian masyarakat Tangerang wilayah pesisir menjadi konsentrasi studi deskripsi ini. Kajian mengenai tingkat integrasi umat Buddha ini akan menjadi cerminan dan upaya penanggulangan terjadinya konflik yang lebih besar. Oleh sebab itu, penelitian ini bertujuan untuk mengenal integrasi sosial yang terjadi pada umat Buddha Tangerang pesisir.

Berdasarkan latar belakang masalah di atas, masalah-masalah dalam penelitian ini dapat diidentifikasikan sebagai berikut: (a) adanya potensi konflik karena banyaknya keragaman budaya, agama, asal daerah masyarakat yang bertempat tinggal di wilayah Tangerang bagian pesisir; (b) munculnya permasalahan sosial yang terjadi karena adanya benturan budaya antarkelompok dan etnis; (c) banyaknya konflik atas nama agama dan rumah ibadah di Indonesia yang berimbas pada keharmonian dan kerukunan umat beragama di wilayah lain, khususnya Tangerang; (d) benturan individu dengan segala kepentingannya berdampak pada potensi konflik yang berkepanjangan; dan (e) integrasi sosial umat Buddha di wilayah Tangerang Pesisir belum tergambar dengan jelas. 
Penelitian ini membatasi masalah pada belum terdeskripsikannya integrasi sosial umat Buddha Tangerang Pesisir. Lokus penelitian dibatasi pada wilayah Tangerang bagian Utara yang dekat dengan laut dikenal sebagai daerah pesisiran, yang tersebar aktif di berbagai vihāra, yaitu Vihāra Tri Maha Dharma, Cetiya Kusala Cetana, Vihara Tri Dharma Carya, Vihāra Isipatana, Vihāra Atthanaga Vimutthi, dan Bodhisatta Buddhist Center.

Penelitian ini diharapkan dapat memberi kontribusi bagi beberapa kalangan, yaitu: (a) masukan bagi masyarakat luas mengenai deskripsi integrasi umat Buddha dengan berbagai permasalahan sosial; (b) bagi rohaniawan menjadi masukan untuk melaksanakan pembinaan umat Buddha; dan (c) bagi STABN Sriwijaya hasil penelitian menjadi dasar dalam pengembangan proses pendidikan dan pembelajaran yang dilaksanakan.

Kegiatan masyarakat yang dinamis dari segi struktur maupun fungsional menghasilkan konsekuensi proses dan interaksi antarkomponennya. Keluarga sebagai sistem terkecil pada masyarakat terdiri dari individu-individu yang memiliki peran di masyarakat. Proses interaksi sosial terjadi jika masing-masing peran dalam sistem masyarakat menuntut adanya komunitas yang harmoni dalam konteks hidup bersama. Menurut Soerjono Soekanto (2006: 55), proses sosial merupakan cara-cara berhubungan yang dapat dilihat apabila para individu dan kelompok-kelompok saling bertemu dan menentukan sistem serta bentuk hubungan tersebut atau apa yang akan terjadi apabila ada perubahan-perubahan yang menyebabkan goyahnya cara-cara hidup yang telah ada. Sistem yang dibentuk oleh masyarakat menentukan jenis interaksi sosial yang ada. Perubahan sistem akan menjadi isu besar dan goncangan dalam masyarakat jika tidak ada pengetahuan dan pemahaman mengorganisasikan konflik karena beragamnya pandangan maupun karakteristik masyarakat.

Perbedaan kedudukan sosial, suku, ras, agama, bahasa, dan kebudayaan dalam masyarakat dapat menyebabkan konflik. Perbedaan dalam masyarakat secara alami memerlukan situasi integratif untuk mencegah disintegrasi yang berdampak pada permasalahan sosial yang lebih luas. Menurut Elly M. Setiadi \& Usman Kolip (2011: 389391) integrasi sosial beragam jenis sesuai dengan tingkat keluasan wilayah geografis komunitas yaitu keluarga, kekerabatan, asosiasi, masyarakat, suku bangsa, dan bangsa.

Integrasi sosial merupakan upaya penyelarasan berbagai perbedaan agar dapat dicapai kesatuan kehidupan dalam wadah asosiasi sosial. Pembangunan yang dilaksanakan dalam suatu negara memerlukan situasi integratif di dalam negara tersebut sebab disintegrasi akan menimbulkan permasalahan sosial, seperti konflik yang tak terkendali sehingga mengancam keutuhan dalam kehidupan berbangsa dan bernegara. Asumsi ini tidak mengesampingkan konflik sosial sebagai gejala ilmiah, namun bagaimana asosiasi sosial mewadahi berbagai perbedaan antarunsur pembentuknya dalam suatu kesatuan. Konflik merupakan gejala sosial alamiah yang akan terus ada dalam setiap aspek, sehingga antara konflik dan integrasi akan selalu ada secara beriringan. Integrasi terjadi karena adanya perasaan satu kelompok dari setiap individu dan merasa ada kelompok lain di luar kelompok dirinya. Perasaan ini memunculkan adanya usaha kerja sama di dalam kelompoknya untuk mempertahankannya. Kerja sama ini akan lebih kuat karena perasaan senasib sepenanggungan, apalagi jika ada ancaman dan bahaya yang datang dari luar kelompoknya.

Menurut Elly M. Setiadi \& Usman Kolip (2011: 389-391), integrasi sosial dikelompokkan menjadi enam yaitu: (a) integrasi keluarga, (b) integrasi kekerabatan, (c) 
integrasi asosiasi (perkumpulan), (d) integrasi masyarakat, (e) integrasi suku bangsa, dan (e) integrasi bangsa. Integrasi keluarga dapat terjadi jika masing-masing anggotanya memahami peran dan fungsinya masing-masing. Peran dan fungsi ini antara keluarga yang satu dengan lainnya bisa sama atau berbeda sesuai kesepakatan dan perjanjian pada keluarga tersebut. Integrasi kekerabatan jika hubungan sosial yang diikat oleh pertalian darah dan hubungan perkawinan antaranggotanya mematuhi nilai-nilai, norma-norma, dan kedudukan, serta peranan sosial yang diakui bersama oleh seluruh anggota kekerabatan yang ada. Integrasi asosiasi (perkumpulan) terjadi jika satuan sosial yang ditandai kesamaan kepentingan memiliki kesamaan minat, tujuan, kepentingan, dan kegemaran.

Pengertian integrasi memiliki makna pembauran hingga menjadi kesatuan yang utuh atau bulat. Istilah pembauran tersebut mengandung arti masuk ke dalam, menyesuaikan, menyatu, atau melebur sehingga menjadi seperti satu. Kata sosial memiliki makna berkenaan dengan masyarakat dan pengertian integrasi sosial adalah sebagai proses penyesuaian di antara unsur-unsur yang saling berbeda dalam kehidupan masyarakat sehingga menghasilkan pola kehidupan masyarakat yang memilki keserasian fungsi.

Kemajemukan sosial menjadi cerminan integrasi sosial karena berbagai komponen yang berbeda dalam masyarakat mencapai suatu kehidupan bermasyarakat. Integrasi sosial merupakan proses penyesuaian unsur-unsur yang saling berbeda dalam kehidupan masyarakat sehingga menghasilkan pola kehidupan masyarakat yang memiliki keserasian fungsi. Dengan demikian, unsur-unsur integrasi sosial dapat dikatakan sebagai pembauran atau penyesuaian dan fungsional. Jika kemajemukan sosial gagal mencapai pembauran atau penyesuaian satu sama lain, maka akan mengalami disintegrasi sosial.

Integrasi sosial dapat terjadi pada daerah atau negara yang multikultur seperti di Indonesia yang memiliki banyak suku, ras, adat, agama, dan budaya yang berbeda-beda seperti dijelaskan bahwa ada sebagian yang tidak menyetujui bahwa Indonesia merupakan negara multikultural, tetapi realitanya Indonesia memang negara multikultur (Zuly Qodir, 2011: 189). Pendapat ini menjelaskan bahwa Indonesia merupakan negara yang memiliki banyak budaya dan kebiasaan yang berbeda-beda.

Berbagai suku, ras, agama, dan bahasa yang ada di Indonesia akan memunculkan dua kemungkinan yaitu kebencian dan toleransi, maka diperlukan solusi atau cara agar tercipta perdamaian dalam kehidupan bermasyarakat. Seperti dijelaskan bahwa agar setiap perbedaan tersebut dapat hidup berdampingan, maka perlu penyelarasan berbagai perbedaan tersebut agar dapat tercapai kesatuan kehidupan dalam suatu wadah baik wadah sosial atau asosial (Usman Kolip, 2010: 387).

Integrasi sosial dalam masyarakat dapat terjadi pada individu ataupun kelompok seperti dijelaskan bahwa terdapat macam-macam integrasi sosial antara lain integrasi keluarga, integrasi kekerabatan, integrasi perkumpulan, Integrasi masyarakat, dan integrasi suku bangsa (Usman Kolip, 2010: 391). Untuk meningkatkan integrasi sosial maka pada diri masing-masing harus dapat mengendalikan perbedaan atau konflik yang ada pada suatu bangsa, dan setiap warga masyarakat dapat saling mengisi kebutuhan antara satu dengan lainnya.

Rasa saling menghormati dan saling menolong adalah kunci hidup damai dalam masyarakat. Integrasi sosial dalam kehidupan bermasyarakat merupakan salah satu cara agar tecipta hidup damai dalam keragaman budaya, untuk itu perlu diketahui bahwa 
perdamaian tidak hanya berkaitan dengan usaha mereduksi kekerasan langsung tetapi juga pada pengembangan vertikal sosial yang bertanggung jawab terhadap hubungan heirarkis sesama manusia (Novri Susan, 2010: 137).

Integrasi sosial didefinisikan sebagai pembauran yang membentuk suatu kesatuan. Definisi integrasi sosial dipandang dari segi sosiologi merupakan suatu proses penyesuaian beragam unsur yang berbeda dalam kehidupan bermasyatakat sehingga memiliki keserasian fungsi, yang dalam hal ini mencakup unsur pembauran atau penyesuaian dan unsur fungsional (Eka Hendry Ar., dkk., 2013: 194).

Perilaku yang solider terbentuk dari beberapa aspek, meliputi kepribadian seseorang, keterampilan, ataupun sejarah pembelajaran yang dimiliki oleh orang tersebut, situasi sosial dan situasi budaya. Aspek tersebut membentuk hubungan mental seseorang dengan orang lain, yang menciptakan perilaku solider. Perilaku solider dapat terjadi dikarenakan faktor transsituasional yang berkaitan dengan budaya dan kelembagaan, konteks, dan sifat kepribadian individu. Perilaku sosial dibentuk dari beberapa faktor penting yang mempengaruhi proses kognitif dan model mental bergantung pada situasi yang ada, yaitu elemen sosial (ketergantungan, perbedaan status, batasan hukum dan norma, sistem kepercayaan dan agama) dan sifat stabil dan keterampilan seseorang (Fetchenhauer, Detlev, et al., 2006: 26).

\section{METODE PENELITIAN}

Penelitian ini didesain menggunakan pendekatan kuantitatif deskriptif untuk menggambarkan integrasi sosial umat Buddha Tangerang pesisir. Studi deskriptif berdasarkan data kuantitatif dimaksudkan untuk memberikan pemahaman secara komprehensif mengenai integrasi sosial umat Buddha. Gambaran mengenai pembauran masyarakat Buddhis di Tangerang pesisir yang multietnik menjadi dasar bagi pengambilan data untuk menjelaskan berbagai dimensi integrasi sosial yang terjadi.

Penelitian ini dilaksanakan di daerah pesisir Tangerang yang terdiri dari beberapa kecamatan, yaitu Mauk, Kampung Melayu, Tanjung Burung, Tanjung Pasir, dan Teluk Naga. Waktu penelitian dilakukan selama kurang lebih lima bulan, dimulai dari survei pendahuluan, penyusunan instrumen penelitian, pengambilan data, analisis data, dan penyusunan laporan, yaitu dari Agustus - Desember 2017.

Sampel penelitian diambil dari populasi umat Buddha yang aktif di vihara yang tersebar di berbagai kecamatan di wilayah Tangerang pesisir dengan teknik pengambilan sampel yaitu random sampling. Populasi diperkirakan sejumlah 1.000 responden, dengan sampel sebanyak 294 responden umat Buddha, yang diambil secara acak dari tempat aktifnya di berbagai vihara, yaitu Vihara Tri Maha Dharma, Cetiya Kusala Cetana, Vihara Tri Dharma Carya, Vihara Isipatana, Vihara Atthanaga Vimutthi, dan Bodhisatta Buddhist Center.

Pengumpulan data dilakukan dengan teknik nontes, yaitu menggunakan angket yang berisi tentang dimensi-dimensi integrasi sosial. Kisi-kisi instrumen integrasi sosial dapat dilihat pada tabel berikut.

Tabel 1

Kisi-Kisi Angket Integrasi Sosial

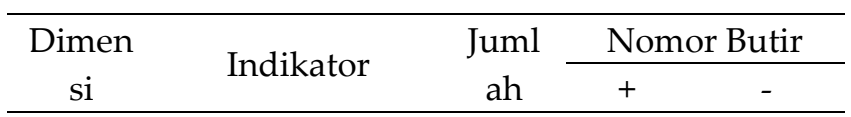




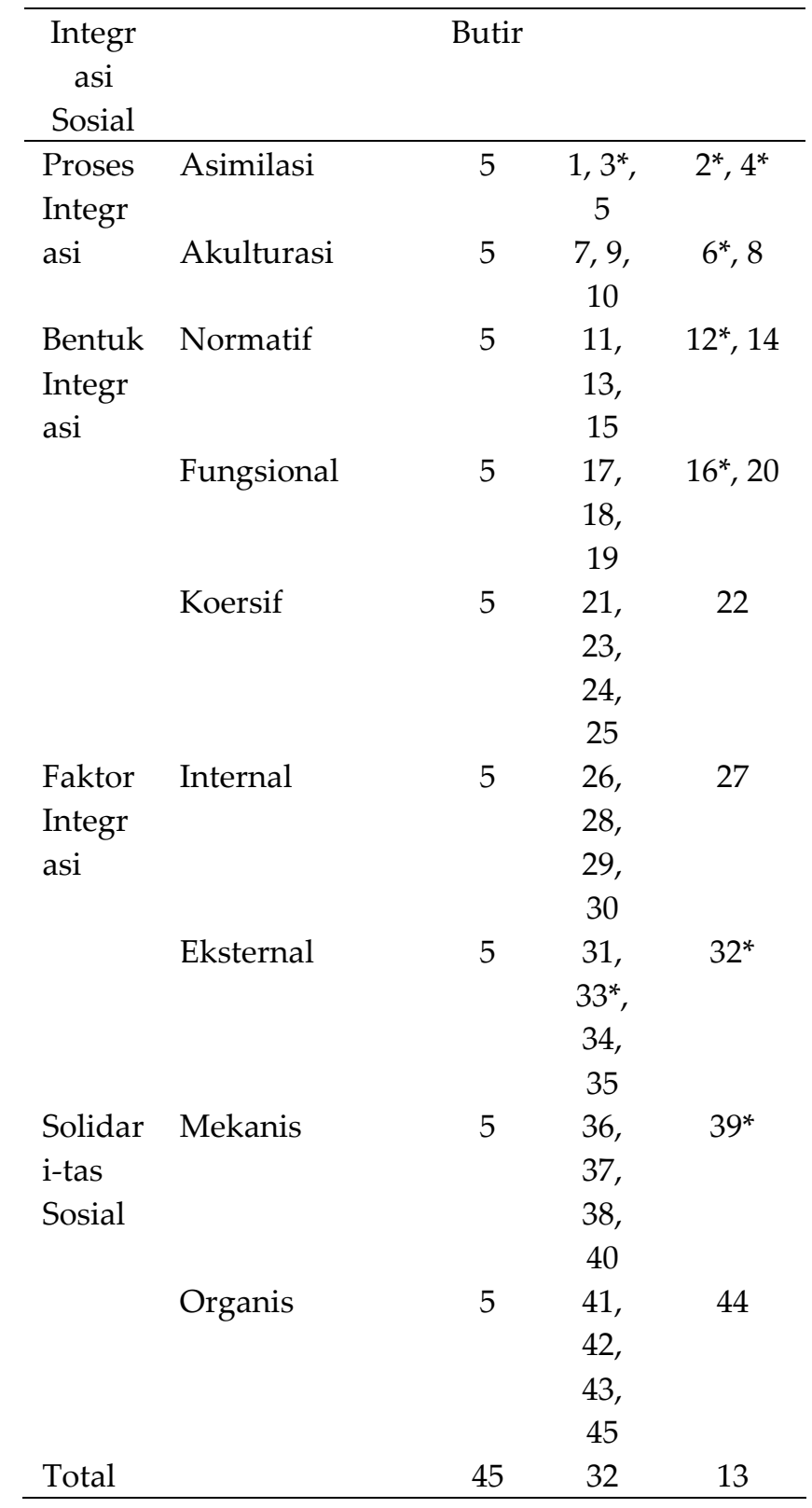

Keterangan: butir pernyataan bertanda * merupakan butir tidak valid

Keabsahan data pada penelitian ini menekankan pada aspek validitas dan reliabilitas instrumen pengumpulan data yang digunakan. Validitas angket integrasi sosial diuji dengan validitas isi (content validity) melalui expert judgement dan validitas konstruk untuk mengetahui seberapa jauh butir-butir dalam angket integrasi sosial mampu mengukur apa yang benar-benar hendak diukur sesuai dengan definisi konseptual yang ditetapkan. Reliabilitas angket integrasi sosial akan menjamin hasil pengukuran dapat dipercaya. Reliabilitas instrumen pada penelitian ini menggunakan rumus koefisien Alpha Cronbach. 
Tabel 2

Validitas Butir Pernyataan Angket Integrasi Sosial

\begin{tabular}{cccccc}
\hline $\begin{array}{c}\text { No. } \\
\text { Butir }\end{array}$ & $\begin{array}{c}\text { Indeks } \\
\text { Korelasi }\end{array}$ & $\begin{array}{c}\text { No. } \\
\text { Butir }\end{array}$ & $\begin{array}{c}\text { Indeks } \\
\text { Korelasi }\end{array}$ & $\begin{array}{c}\text { No. } \\
\text { Butir }\end{array}$ & $\begin{array}{c}\text { Indeks } \\
\text { Korelasi }\end{array}$ \\
\hline 1 & 0.330 & $16^{*}$ & 0.061 & 31 & 0.376 \\
$2^{*}$ & -0.040 & 17 & 0.454 & $32^{*}$ & -0.019 \\
$3^{*}$ & 0.097 & 18 & 0.533 & $33^{*}$ & -0.008 \\
$4^{*}$ & 0.047 & 19 & 0.206 & 34 & 0.344 \\
5 & 0.276 & 20 & 0.256 & 35 & 0.366 \\
$6^{*}$ & 0.061 & 21 & 0.347 & 36 & 0.520 \\
7 & 0.277 & 22 & 0.285 & 37 & 0.359 \\
8 & -0.346 & 23 & 0.436 & 38 & 0.547 \\
9 & 0.496 & 24 & 0.421 & $39^{*}$ & 0.025 \\
10 & 0.242 & 25 & 0.499 & 40 & 0.163 \\
11 & 0.358 & 26 & 0.263 & 41 & 0.532 \\
$12^{*}$ & -0.022 & 27 & -0.183 & 42 & 0.266 \\
13 & 0.227 & 28 & 0.479 & 43 & 0.522 \\
14 & 0.165 & 29 & 0.614 & 44 & -0.162 \\
15 & 0.338 & 30 & 0.465 & 45 & 0.331 \\
\hline
\end{tabular}

Keterangan: butir angket bertanda * merupakan butir tidak valid

Reliabilitas angket integrasi sosial sebesar 0,669 dinyatakan terpercaya karena lebih dari 0,65 (Purwanto, 2007: 185).

Analisis data dilakukan untuk menggambarkan deskripsi variabel integritas sosial umat Buddha Tangerang pesisir. Penelitian ini menggunakan teknik analisis data statistik deskriptif untuk menggambarkan keadaan umat Buddha Tangerang pesisir dilihat dari variabel integrasi sosial, melalui dimensi-dimensi yaitu proses integrasi, bentuk integrasi, faktor integrasi, dan solidaritas sosial. Untuk mengetahui tingkat integrasi sosial umat Buddha digunakan rumus sebagai berikut (Healey, 2010: 30):

$$
\%=\frac{\text { Skor yang diperoleh }}{\text { Skor ideal }} \times 100
$$

\section{PEMBAHASAN}

Penelitian ini bertujuan untuk mengetahui tingkat integrasi sosial umat Buddha wilayah Tangerang Pesisir. Integrasi sosial umat dilihat dari proses integrasi, bentuk integrasi, faktor integrasi, dan solidaritas sosial yang terjadi selama ini di tengah masyarakat. Dimensi integrasi sosial ini diturunkan dari teori yang mencerminkan aspek-aspek yang mencerminkan umat Buddha sebagai komunitas memiliki tingkat adaptasi dalam suatu kehidupan masyarakat. Upaya integrasi sosial pada dasarnya adalah pengendalian terhadap adanya konflik yang diakibatkan karena gesekan suku, agama, ras, dan antargolongan. Umat Buddha memandang diri dan komunitasnya bagaimana tingkat integrasi sosial yang telah berlangsung dalam berinteraksi dengan lingkungannya yang plural. Hasil penelitian dapat dideskripsikan sebagai berikut.

Tabel 3

Statistik Deskriptif 
Integrasi Sosial Umat Buddha

\begin{tabular}{|c|c|c|c|c|}
\hline \multirow[b]{2}{*}{ Aspek } & \multicolumn{3}{|c|}{ Standa } & \multirow[b]{2}{*}{$\begin{array}{c}\text { Rang } \\
\mathrm{e}\end{array}$} \\
\hline & $\begin{array}{c}\text { Mea } \\
\mathrm{n}\end{array}$ & $\begin{array}{c}\mathrm{r} \\
\text { Devias } \\
\mathrm{i}\end{array}$ & $\begin{array}{c}\text { Varian } \\
\mathrm{s}\end{array}$ & \\
\hline Integrasi & 101,9 & 10,06 & 101,16 & 59,00 \\
\hline Sosial & 3 & & & \\
\hline $\begin{array}{l}\text { Proses } \\
\text { Integrasi }\end{array}$ & 15,22 & 3,02 & 9,09 & 38,00 \\
\hline $\begin{array}{l}\text { Bentuk } \\
\text { Integrasi }\end{array}$ & 37,51 & 4,51 & 20,35 & 24,00 \\
\hline $\begin{array}{l}\text { Faktor } \\
\text { Integrasi }\end{array}$ & 24,04 & 2,49 & 6,18 & 14,00 \\
\hline $\begin{array}{l}\text { Solidarita } \\
\text { s Sosial }\end{array}$ & 25,16 & 3,21 & 10,28 & 16,00 \\
\hline
\end{tabular}

Integrasi sosial umat Buddha memiliki rerata skor 101,93; standar deviasi 10,06; varians 101,16; dan rentang 59,00 dari selisih skor maksimum 134,00 dan skor minimum 75,00 .

Berdasarkan statistik deskriptif dengan menggunakan parameter rerata dan standar deviasi diperoleh kategori tinggi, sedang, dan rendah; baik untuk tingkat integrasi sosial, maupun masing-masing dimensinya. Kriteria kategori tinggi, sedang, dan rendah masing-masing hasil penelitian dapat dilihat pada tabel berikut.

Tabel 4

Kriteria Kategori Masing-Masing Aspek Penelitian

\begin{tabular}{llccc}
\hline No. & Aspek & Tinggi & Sedang & Rendah \\
\hline 1. & Integrasi Sosial & $>=112$ & $92-111$ & $<92$ \\
2. & Proses Integrasi & $>=18$ & $12-17$ & $<12$ \\
3. & Bentuk Integrasi & $>=42$ & $33-41$ & $<33$ \\
4. & Faktor Integrasi & $>=27$ & $22-26$ & $<22$ \\
5. & Solidaritas Sosial & $>=28$ & $22-27$ & $<22$ \\
\hline
\end{tabular}

Distribusi frekuensi masing-masing kategori masing-masing aspek dinyatakan pada tabel berikut.

Tabel 5

Distribusi Frekuensi Kategori Masing-Masing Aspek Penelitian

\begin{tabular}{llccc}
\hline $\begin{array}{l}\text { N } \\
\text { o. }\end{array}$ & Aspek & Tinggi & $\begin{array}{c}\text { Seda } \\
\mathrm{ng}\end{array}$ & $\begin{array}{c}\text { Rend } \\
\mathrm{ah}\end{array}$ \\
\hline 1. & $\begin{array}{l}\text { Integrasi } \\
\text { Sosial }\end{array}$ & 58 & 204 & 32 \\
2. & $\begin{array}{l}\text { Proses } \\
\text { Integrasi }\end{array}$ & 50 & 229 & 15
\end{tabular}




\begin{tabular}{lllll} 
3. & $\begin{array}{l}\text { Bentuk } \\
\text { Integrasi }\end{array}$ & 59 & 197 & 38 \\
4. & $\begin{array}{l}\text { Faktor } \\
\text { Integrasi }\end{array}$ & 49 & 212 & 33 \\
5. & $\begin{array}{l}\text { Solidaritas } \\
\text { Sosial }\end{array}$ & 58 & 203 & 33 \\
\hline
\end{tabular}

Tingkat integrasi sosial umat Buddha wilayah Tangerang Pesisir dan masingmasing aspek, dalam persentase dapat dilihat pada tabel berikut ini.

Tabel 6

Tingkat Integrasi Sosial Umat Buddha Tangerang Pesisir

\begin{tabular}{clcc}
\hline No. & Aspek & $\begin{array}{c}\text { Tingkat } \\
\text { (Persentase) }\end{array}$ & Kriteria \\
\hline 1. & $\begin{array}{l}\text { Integrasi } \\
\text { Sosial }\end{array}$ & $71 \%$ & Baik \\
2. & $\begin{array}{l}\text { Proses } \\
\text { Integrasi } \\
\text { Bentuk } \\
\text { Integrasi }\end{array}$ & $72 \%$ & Cukup \\
4. & $\begin{array}{l}\text { Faktor } \\
\text { Integrasi } \\
\text { Solidaritas } \\
\text { Sosial }\end{array}$ & $75 \%$ & Baik \\
\hline
\end{tabular}

Distribusi frekuensi integrasi sosial masing-masing wilayah berdasarkan tempat aktifnya umat Buddha berbasis vihara asal dapat dilihat pada tabel berikut ini.

Tabel 7

Distribusi Frekuensi

Kategori Integrasi Sosial Umat Buddha Berdasarkan Vihara Asal

\begin{tabular}{lccc}
\hline Vihara Asal & $\begin{array}{c}\text { Ting } \\
\text { gi }\end{array}$ & $\begin{array}{c}\text { Seda } \\
\text { ng }\end{array}$ & $\begin{array}{c}\text { Rend } \\
\text { ah }\end{array}$ \\
\hline Tri Maha Dharma & 8 & 40 & 2 \\
Kusala Cetana & 1 & 47 & 2 \\
Tri Dharma Carya & 17 & 31 & 0 \\
Isipatana & 20 & 30 & 0 \\
Atthanaga & 0 & 23 & 27 \\
Vimutthi & & & \\
Bodhisatta & 12 & 33 & 1 \\
Buddhist Center & & & \\
\hline
\end{tabular}

Integrasi sosial umat Buddha merupakan interaksi antara individu dan individu, individu dengan kelompok, serta kelompok dengan kelompok yang saling berorientasi 
dalam memiliki perasaan in group terhadap kelompoknya, dan ada kelompok lain di luar kelompoknya (out group). Integrasi sosial tampak pada dimensi atau aspek pembentuknya, di antaranya proses integrasi, bentuk integrasi, faktor integrasi, dan solidaritas sosial. Kategori integrasi sosial umat Buddha berdasarkan vihara asal menggambarkan pemetaan dan variasi integrasi umat Buddha di masyarakat. Pemetaan ini memberikan penjelasan tentang wilayah mana yang memiliki integrasi sosial lebih tinggi dibanding lainnya. Integrasi sosial umat Buddha bisa jadi dipengaruhi oleh berbagai faktor, di antaranya latar belakang pendidikan responden, jenis kelamin, pekerjaan, budaya, dll. Proses, bentuk, faktor, dan solidaritas sosial umat Buddha mencerminkan tingkat integrasi sosial umat Buddha. Variasi dan pemetaan integrasi sosial umat Buddha berdasarkan asal vihara dijadikan pedoman dalam pembinaan dan penyuluhan. Gambaran integrasi sosial umat Buddha dan aspek-aspeknya dapat dilihat pada gambar berikut.

Gambar 1

Diagram Batang

Integrasi Sosial Umat Buddha

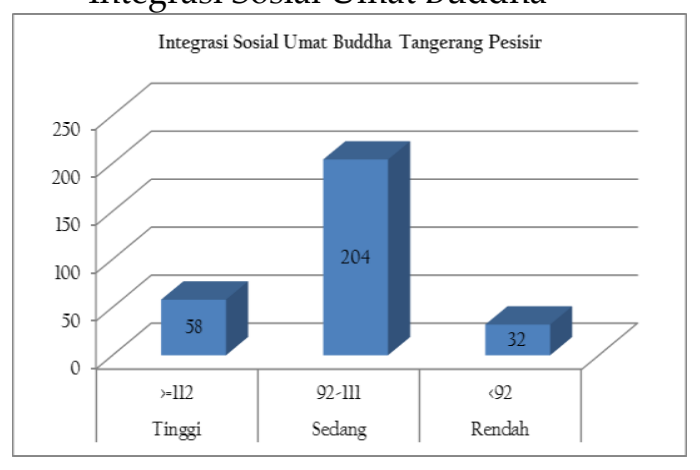

Gambar 2

Diagram Batang Tingkat Integrasi Sosial Umat Buddha

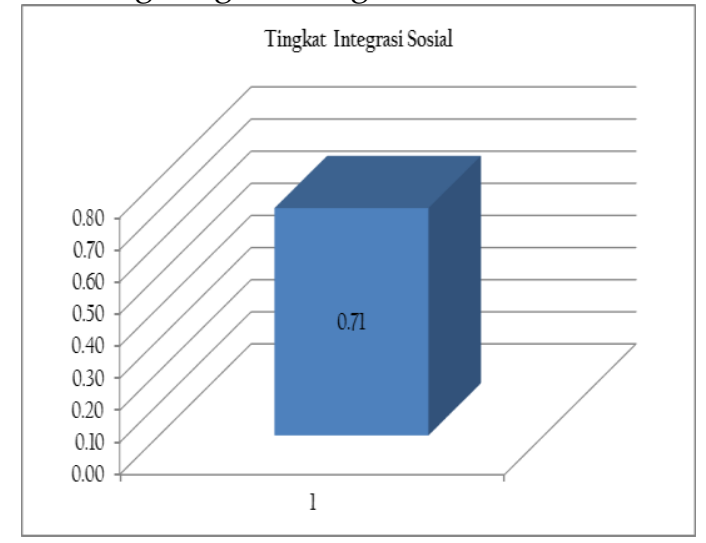

Gambar 3 
Diagram Batang Proporsi Integrasi Sosial Umat Buddha

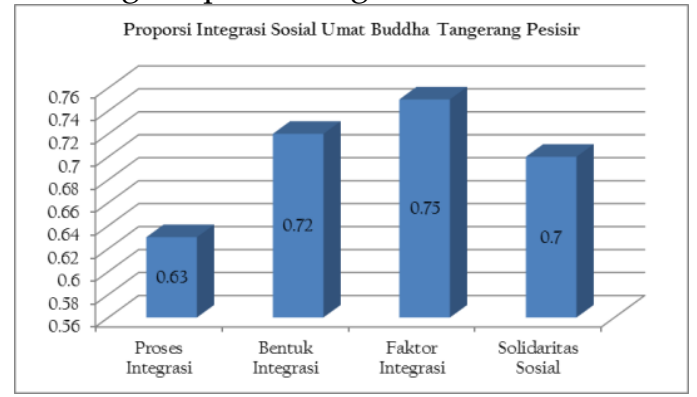

Gambar 4

Diagram Batang Proses Integrasi Sosial Umat Buddha

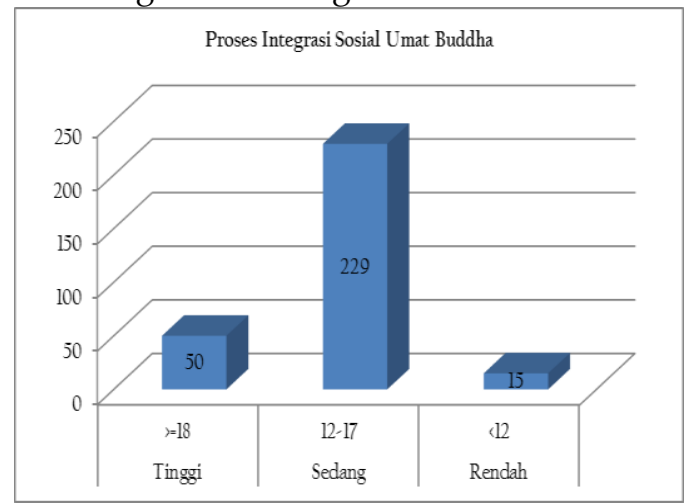

Gambar 5

Diagram Batang Bentuk Integrasi Sosial Umat Buddha

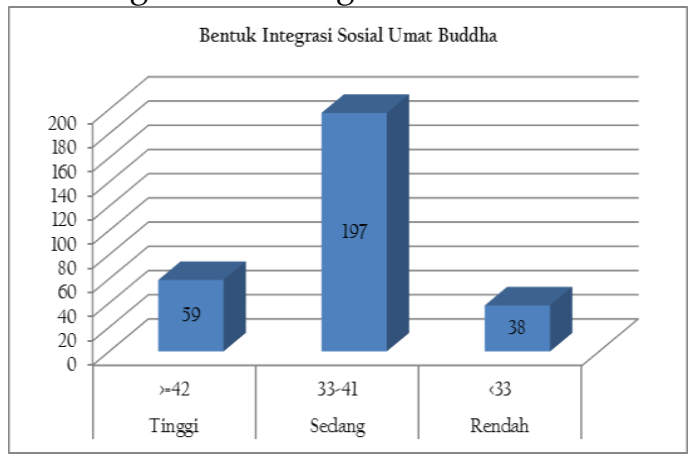

Gambar 6

Diagram Batang Faktor Integrasi Sosial Umat Buddha

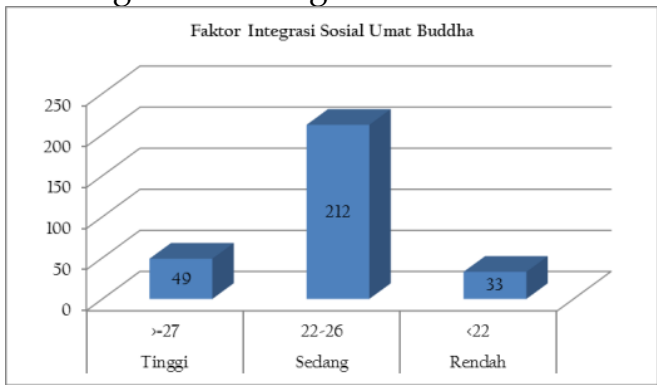


Gambar 7

Diagram Batang Solidaritas Sosial Umat Buddha

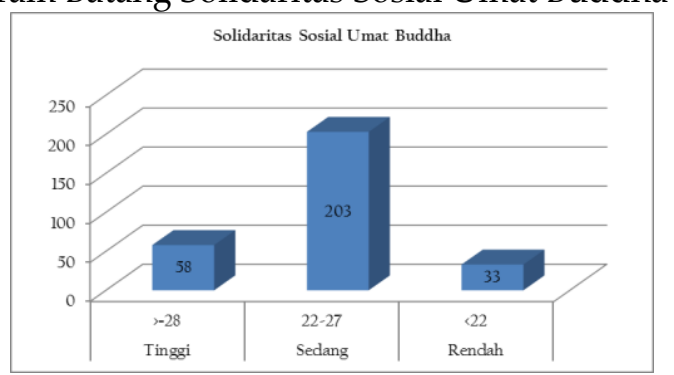

Gambar 8

Diagram Batang Perbandingan Kategori Integrasi Sosial Umat Buddha

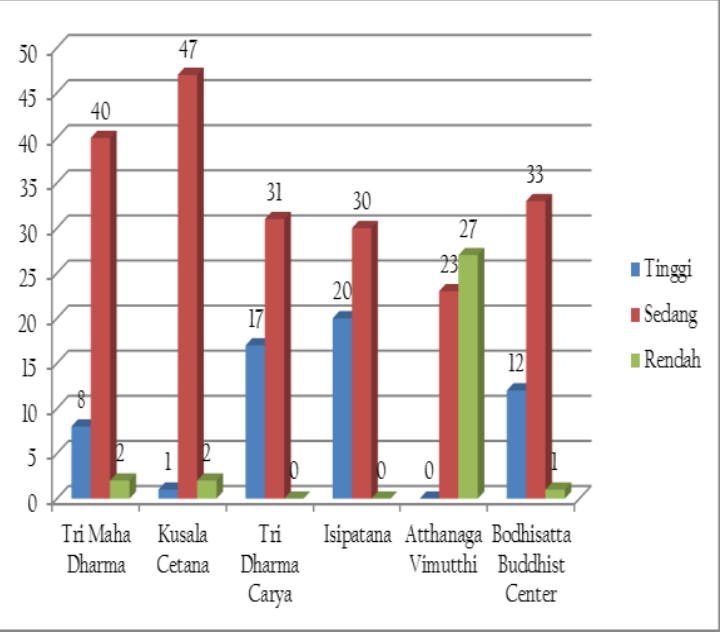

Penelitian ini bertujuan untuk menggambarkan tingkat integrasi sosial umat Buddha wilayah Tangerang Pesisir yang multietnik dan plural. Responden terdiri dari 294 orang umat Buddha dengan latar belakang yang aktif dari vihara asal yang berbeda. Permasalahan utama penelitian ini adalah belum tergambarkannya integrasi sosial umat Buddha Tangerang Pesisir. Hasil penelitian menunjukkan tingkat integrasi umat Buddha, yang meliputi aspek-aspek dimensinya yaitu proses integrasi, bentuk integrasi, faktor integrasi, dan solidaritas sosial.

Penelitian ini menggunakan instrumen berupa angket integrasi sosial umat Buddha yang dikembangkan oleh peneliti. Instrumen divalidasi menggunakan expert judgment yang terdiri dari dua orang. Hasil telaah pakar ini direvisi dan diperbaiki untuk kemudian digunakan dalam pengumpulan data. Validasi empirik dianalisis dengan program spss menghasilkan butir tidak valid sebanyak delapan butir, yaitu nomor 2, 3, 4, $6,12,16,32,33$ atau sebanyak $20 \%$ dari jumlah butir 45 . Butir yang tidak valid sebagian besar didominasi oleh butir unfavorable. Hal ini dimungkinkan karena bunyi pernyataan yang bias, bermakna ganda, atau sulit dipahami oleh responden sebagai pernyataan yang negatif. Butir-butir yang tidak valid langsung di-drop dan tidak direvisi. Hal ini dapat ditempuh karena masih terdapat butir lain untuk menyatakan indikator dari dimensi yang bersangkutan.

Tingkat integrasi umat Buddha Tangerang Pesisir sebesar 71\%, tergolong kategori baik. Responden sebanyak 294 umat Buddha memiliki kualitas membaur dengan 
masyarakatnya dalam kategori baik. Pembauran yang baik dan merasa in group dengan masyarakatnya menjadi modal yang baik untuk mencegah terjadinya konflik. Keharmonisan masyarakat menjadi tujuan umat Buddha, khususnya di wilayah Tangerang Pesisir. Walaupun integrasi umat Buddha Tangerang Pesisir termasuk kategori baik, namun demikian masih dimungkinkan munculnya potensi konflik sebagai akibat adanya integrasi sosial. Umat Buddha masih memiliki kecenderungan eksklusif, baik dalam proses, berintegrasi, memunculkan faktor integrasi, maupun peran dalam menjaga solidaritas sosial. Peran aktif tokoh agama yang dijadikan panutan dan teladan oleh umat Buddha memiliki fungsi strategis dalam menguatkan solidaritas dan proses integrasi sosial. Penyuluhan dan sosialisasi mengenai pentingnya menjaga integrasi sosial sebagai jaminan pencegahan konflik harus menjadi bahan dan materi tokoh agama agar pesan yang dibawa sampai kepada umat Buddha.

Proses integrasi umat Buddha Tangerang Pesisir memiliki tingkat 63\%, tergolong kategori cukup. Hal ini mencerminkan tingkat asimilasi dan akomodasi umat Buddha Tangerang Pesisir tergolong cukup dalam mengintegrasikan dirinya ke dalam masyarakatnya. Dengan kata lain, masih terdapat keengganan dalam diri umat Buddha Tangerang Pesisir jika bertemu dengan kebudayaan lain tanpa harus meninggalkan kebudayaan aslinya. Sebab ini dipahami sebagai ciri manusia yang berbudaya dan tidak mudah begitu saja meninggalkan kebudayaan leluhurnya. Di antara unsur atau dimensi integrasi sosial, proses integrasi berada pada urutan terbawah dengan kategori cukup. Hal ini dimungkinkan masih adanya sikap antipati terhadap unsur budaya luar. Dengan kata lain, umat Buddha cenderung melihat kebudayaan yang diyakini dari leluhurnya menjadi prioritas dan panduan dalam berperilaku di masyarakat yang plural. Hal ini dapat dipahami sebagai upaya untuk menjaga keluhuran budaya nenek moyang dengan dalih melestarikannya.

Bentuk integrasi sosial umat Buddha Tangerang Pesisir memiliki tingkat 72\%, tergolong kategori baik. Secara normatif, fungsional, dan koersif umat Buddha Tangerang Pesisir tergolong kategori baik. Hal ini berarti bahwa umat Buddha baik dalam merespons aturan atau norma yang bertujuan untuk mengikat dan mewujudkan keharmonisan masyarakat. Bentuk integrasi sosial umat Buddha Tangerang Pesisir yang meliputi normatif, fungsional, dan koersif menjadi dasar pertimbangan dalam berinteraksi di masyarakat. Ketaatan pada norma dan hukum sebagai aturan bersama dalam hidup bermasyarakat digunakan oleh umat Buddha sebagai cara mudah dalam berinteraksi dengan masyarakatnya. Bahkan, umat Buddha berperan serta dalam memberikan masukan terhadap norma dan hukum yang digunakan bersama berdasarkan norma dan ajaran yang dianutnya. Demikian pula, secara fungsional umat Buddha menjadikan semangat nasionalisme dan simbol-simbol kenegaraan sebagai perekat sosial dalam rangka mencegah terjadinya konflik. Dengan kata lain, umat Buddha Tangerang Pesisir memiliki peran aktif dalam menjaga stabilitas masyarakat yang rentan terhadap konflik, terutama karena isu SARA. Secara koersif, umat Buddha Tangerang Pesisir mendukung upaya Pemerintah dalam menegakkan hukum dan norma demi terciptanya stabilitas masyarakat dan mencegah terjadinya konflik. Lebih lanjut, umat Buddha Tangerang Pesisir mendukung upaya penegakan hukum dengan memberikan sanksi yang sesuai dengan pelanggaran yang diperbuat oleh anggota masyarakat. Bentuk integrasi koersif juga bermakna bahwa aparat Pemerintah dapat memberi efek jera kepada pelaku tindak pidana dengan memberikan sanksi secara tegas 
dan keras. Hal ini semata-mata ditegakkan dalam rangka menumbuhkan masyarakat yang memiliki kesadaran hukum yang tinggi.

Faktor-faktor integrasi sosial umat Buddha Tangerang Pesisir memiliki tingkat 75\%, kategori baik. Aspek ini paling tinggi dibandingkan aspek lain dari dimensi penelitian. Hal itu berarti bahwa faktor internal dan eksternal sangat mempengaruhi dalam integrasi sosial umat Buddha. Faktor internal yang mendasari integrasi sosial, di antaranya kesadaran diri sebagai makhluk sosial, tuntutan kebutuhan, dan semangat gotong royong. Faktor eksternal meliputi tuntutan zaman, toleransi, persamaan kebudayaan, dan konsensus nilai. Faktor integrasi umat Buddha Tangerang Pesisir memiliki peran besar dalam mendukung terjadinya integrasi sosial di masyarakat. Faktor ini terdiri dari faktor internal dan eksternal. Kesadaran diri sebagai makhluk sosial diyakini benar oleh umat Buddha dalam membawa diri di masyarakat, di samping adanya tuntutan kebutuhan maupun semangat gotong royong. Tuntutan kebutuhan dimaksudkan untuk mengurus berbagai kepentingan yang mengharuskan umat Buddha untuk berinteraksi dengan masyarakat. Namun demikian, adanya tuntutan kebutuhan ini juga dapat dipandang sebagai sebuah keharusan yang agak memaksa. Toleransi dan persamaan budaya sebagai faktor eksternal integrasi sosial menjadi kebutuhan mutlak di era sekarang karena adanya banyak pengalaman di daerah lain yang muncul banyak konflik.

Solidaritas sosial umat Buddha Tangerang Pesisir berada pada tingkat $70 \%$, dengan kategori baik. Solidaritas ini sebagai syarat terjadinya integrasi sosial, yang terdiri dari solidaritas mekanis dan organis. Solidaritas sosial mekanis menjamin umat Buddha untuk menghargai kelompok lain walaupun dirinya sendiri memiliki tradisi yang berbeda. Solidaritas sosial organis menuntut umat Buddha memberikan peran dirinya untuk terlibat pada urusan bersama.

\section{SIMPULAN}

Penelitian mengenai integrasi sosial umat Buddha wilayah pesisir Tangerang menghasilkan kesimpulan sebagai berikut:

1. Tingkat integrasi sosial umat Buddha Tangerang Pesisir sebesar 71\% (baik), dengan kategori tinggi sebesar $20 \%$, sedang $69 \%$, dan rendah $11 \%$. Hasil ini memberikan implikasi pada peran umat Buddha wilayah Tangerang Pesisir dalam berperan serta pada pembangunan masyarakat yang mengedepankan pluralitas dan toleransi untuk mencegah terjadinya konflik dengan menguatkan perasaan in group terhadap kelompoknya.

2. Proporsi integrasi sosial umat Buddha Tangerang Pesisir berdasarkan dimensi variabel, yaitu $1,00: 1,14: 1,19: 1,11$; dengan rincian persentase masing-masing sebagai berikut: (a) proses integrasi sebesar $63 \%$, (b) bentuk integrasi sebesar $72 \%$, (c) faktor integrasi sebesar 75\%, dan (d) solidaritas sosial sebesar 70\%. Hasil ini berdampak pada penguatan faktor-faktor yang memantapkan integrasi sosial umat Buddha Tangerang Pesisir berupa faktor internal (kesadaran diri sebagai makhluk sosial, tuntutan kebutuhan, dan semangat gotong-royong) dan eksternal (tuntutan zaman, persamaan kebudayaan, terbukanya kesempatan, partisipasi dalam kehidupan bersama, persamaan visi dan tujuan, sikap toleransi, konsensus nilai, dan tantangan dari luar). Faktor internal dan eksternal secara seimbang mampu meneguhkan integrasi sosial umat Buddha wilayah Tangerang Pesisir.

3. Proses integrasi umat Buddha Tangerang Pesisir yang terdiri dari indikator asimilasi dan akulturasi memiliki tingkat sebesar 63\% (cukup), dengan kategori tinggi sebesar 
$17 \%$, sedang $78 \%$, dan tinggi 5\%. Hasil ini membawa implikasi pada peningkatan dan upaya-upaya konsolidasi dalam berhadapan dengan kebudayaan yang berbeda, apakah meninggalkan atau tanpa meninggalkan kebudayaan aslinya.

4. Bentuk integrasi umat Buddha Tangerang Pesisir yang terdiri dari indikator normatif, fungsional, dan koersif memiliki tingkat sebesar $72 \%$ (baik), dengan kategori tinggi sebesar $20 \%$, sedang $67 \%$, dan tinggi $13 \%$. Hasil ini berdampak pada penegakan norma-norma yang berlaku di masyarakat sebagai dasar dalam melakukan integrasi sosial yang berasumsi pada keadilan memperoleh akibat tertentu jika melanggar norma yang berlaku.

5. Faktor integrasi umat Buddha Tangerang Pesisir yang terdiri dari indikator internal dan eksternal memiliki tingkat sebesar 75\% (baik), dengan kategori tinggi sebesar $17 \%$, sedang $72 \%$, dan tinggi $11 \%$. Faktor integrasi menjadi unsur terbesar dalam integrasi sosial umat Buddha, sehingga diperlukan identifikasi faktor utama dalam meningkatkan integrasi sosial umat Buddha. Faktor internal dan eksternal integrasi sosial umat Buddha wilayah Tangerang Pesisir saling bersinergi dalam menguatkan dalam menghindari konflik.

6. Solidaritas sosial umat Buddha Tangerang Pesisir yang terdiri dari indikator mekanis dan organis memiliki tingkat sebesar 70\% (baik), dengan kategori tinggi sebesar 19\%, sedang $70 \%$, dan rendah $11 \%$. Solidaritas sosial sebagai syarat terjadinya pembagian kerja sebagai kewajiban moral perlu dikembangkan dalam menghindari konflik dan perselisihan.

Berdasarkan kesimpulan dan implikasi di atas, peneliti menyarankan beberapa hal sebagai berikut:

1. Bagi umat Buddha wilayah Tangerang Pesisir dan masyarakat umum lainnya, hasil penelitian ini dapat dijadikan landasan dalam mempertahankan dan meningkatkan upaya pencegahan konflik berdasarkan faktor yang mempengaruhi integrasi sosial, yaitu penguatan pada faktor internal (kesadaran diri sebagai makhluk sosial, tuntutan kebutuhan, dan semangat gotong royong) dan eksternal (tuntutan zaman, toleransi, persamaan kebudayaan, dan konsensus nilai).

2. Bagi dharmaduta, hasil penelitian ini dapat dijadikan dasar dalam pemetaan permasalahan konflik keagamaan dan sosial yang terjadi di masyarakat berdasarkan prioritas dimensi pembentuk integrasi sosial umat Buddha wilayah Tangerang Pesisir. Peran aktif dharmaduta dalam memberikan penyuluhan kepada umat Buddha dapat menggunakan hasil penelitian ini sebagai dasar acuan penentuan materi, terutama dalam pencegahan munculnya konflik.

3. Bagi kampus STAB Negeri Sriwijaya, khususnya Program Studi Kepenyuluhan, Jurusan Dharmaduta, penelitian ini menjadi dasar pemetaan penelitian dan pengabdian masyarakat yang dijadikan sebagai pengayaan bahan pendidikan dan pengajaran.

4. Bagi peneliti selanjutnya, hasil penelitian ini dapat dijadikan sebagai acuan dalam melakukan kajian selanjutnya melalui pendalaman metodologi maupun objek penelitian.

\section{DAFTAR PUSTAKA}

Eka Hendry Ar., dkk. 2013. Integrasi Sosial dalam Masyarakat Multietnik. Walisongo: Jurnal Penelitian Sosial Keagamaan. Volume 21, Nomor 1, p. 191-218. 
Elly M. Setiadi \& Usman. Kolip. 2011. Pengantar Sosiologi: Pemahaman Fakta dan Gejala Permasalahan Sosial: Teori, Aplikasi, dan Pencegahannya. Jakarta: Kencana.

Fetchenhauer, Detlev, et al. 2006. Solidarity and Prosocial Behavior: An Integration of Sociological and Psychological Perspectives. Netherlands: Springer.

Healey, Joseph F. 2010. The Essentials of Statistics: A Tool for Social Research. Belmont, CA: Wadsworth.

Iswidodo. 2016. Kronologi dan Penyebab Awal Kerusuhan SARA di Tanjung balai Minggu, 31 Juli 2016 07:10 http://jateng.tribunnews.com/ 2016/07/31/kronologi-danpenyebab-awal-kerusuhan-sara-di-tanjungbalai (diakses 10 September 2017).

KBBI online https://kbbi.web.id/ (diakses 10 September 2017).

Novri Susan, 2010. Pengantar Sosiologi Konflik dan Isu-Isu Konflik Kontemporer. Kencana Prenada Media Group: Jakarta.

Purwanto. 2007. Instrumen Penelitian Sosial dan Pendidikan. Yogyakarta: Pustaka Pelajar.

Soerjono Soekanto. 2006. Sosiologi: Suatu Pengantar. Jakarta: PT RajaGrafindo Persada.

Usman Kolip. 2010. Pengantar Sosiologi. Kencana Prenada Media Group: Jakarta.

Yustinasusi. 2015. Integrasi dan Integrasi Sosial. https://yustinasusi.wordpress.com/2015/03/02/integrasi-dan-integrasi-sosial/ (diakses 12 September 2017).

Zuly Qodir. 2011. Sosiologi Agama. Pustaka Pelajar: Yogyakarta. 